\title{
FLY ASH AND SLAG UTILIZATION FOR THE SERBIAN RAILWAY SUBSTRUCTURE
}

\author{
Mirjana Vukićević, Zdenka Popović, Jovan Despotović, Luka Lazarević \\ Faculty of Civil Engineering, University of Belgrade, Serbia
}

Submitted 14 August 2015; resubmitted 30 December 2015; accepted 24 February 2016; published online 12 December 2016

\begin{abstract}
Approximately 7 million tons of fly ash and slag are produced in thermal power plants in Serbia every year, only $3 \%$ of which is used in the cement industry. About 300 million tons of the ash-slag mixture are disposed in landfills, occupying an area of approximately 1600 hectares and generating environmental issues. Fly ash from Serbian power plants has pozzolanic properties and due to low concentration of calcium compounds (less than $10 \% \mathrm{CaO}$ ), they do not have self-cementing properties. According to the ASTM C618-15, this ash is from class F. According to the European Standard EN 197-1:2011, this ash is siliceous (type V) ash. From April 2014 to May 2015, an investigation of engineering properties of fly ash and mixtures of fly ash and slag from landfill (without or with binders of cement/lime) was conducted at the Laboratory of Soil Mechanics at the Faculty of Civil Engineering of the University of Belgrade (Serbia) and at the Institute for Testing of Materials - IMS Institute in Belgrade. The laboratory test results were showed in the study 'Utilization of fly ash and slag produced in the TPP JP EPS thermal power plants for construction of railways. Four kinds of waste materials from Serbian power plants were laboratory tested: (a) an ash-slag mixture from landfills at the 'Nikola Tesla A' thermal power plant; (b) fly ash from silos in the 'Nikola Tesla B' thermal power plant; (c) an ash-slag mixture from landfills at the 'Kostolac A' and 'Kostolac B' thermal power plants and 'Srednje kostolačko ostrvo' landfill; (d) fly ash from the 'Kostolac' thermal power plant. The following physical and mechanical properties of ash and mixtures were investigated: grain size distribution, Atterberg limits, specific gravity, moisture-density relationship, shear strength parameters in terms of effective stresses, California Bearing Ratio (CBR), and deformation parameters. The paper presents the results of laboratory tests of the materials with and without binders, and based on the laboratory results and previous research, the paper presents possibilities of using fly ash and slag for the construction of railway substructure in the planned construction and reconstruction of railway network in Serbia. The obtained results indicate that tested fly ash and ash-slag mixture have met the technical requirements and that they have the potential to be used in railway substructure.
\end{abstract}

Keywords: railway substructure; embankments; technical requirements; fly ash; slag; laboratory tests.

\section{Introduction}

Two European traffic corridors pass through the Republic of Serbia: the Danube Corridor VII and the roadrailway Corridor X (Fig. 1). Corridor VII (the river Danube) connects Central Europe with the Black Sea via the Republic of Serbia and represents a part of the South East multi-modal axis. Corridor $\mathrm{X}$ with its branches $\mathrm{Xb}$ (Belgrade-Budapest) and $\mathrm{Xc}$ (Nis-Sofia), represents the most significant road-railway route on the territory of the Republic of Serbia. It was established as a part of the South East multi-modal axis, linking Austria/Hungary, Slovenia/Croatia, the Republic of Serbia and Bulgaria/Macedonia/Greece and covers $760 \mathrm{~km}$ of railway lines in the Republic of Serbia. The goal is to improve the railway lines on Corridor X throughout Serbia by reconstructing the existing tracks and constructing the second track on the single-track sections in order to enable all corridor tracks for modern double track traffic and train speeds of $160 \mathrm{~km} / \mathrm{h}$ (Ministarstvo građevinarstva, saobraćaja... 2014).

The railways of Serbia are a part of the European railway network and their development must be in accordance with the European transport policy (Popović, Lazarević 2013; Popović et al. 2013) and technical regulations (Popović et al. 2014). The European transport policy expects a tripling of freight transport on rail by 2020, which will affect the reduction of air pollution and increase of road traffic safety (EC 2011b). In spite

Corresponding author: Luka Lazarević

E-mail: llazarevic@grf.bg.ac.rs 
of that, consequences of this policy might be the adverse environmental impacts of railway traffic such as: increase of noise from railway traffic (expected ca. $5 \mathrm{~dB}$ (A)), use of non-renewable mineral resources for construction of new and reconstruction of existing railway infrastructure (sand, gravel, crushed stone), dumping of waste at landfills, etc.

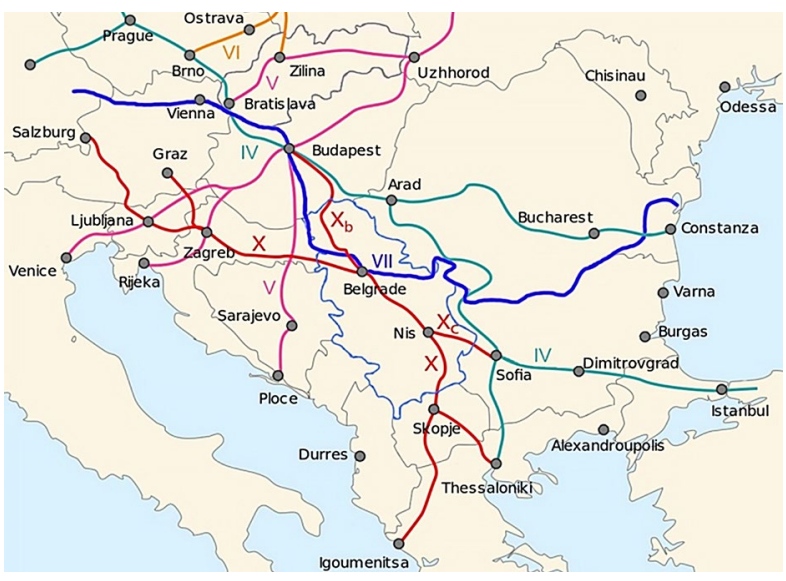

Fig. 1. The European Danube Corridor VII and Corridor X through the Republic of Serbia

Railway infrastructure projects require earth material in very large quantities and with properties in accordance to the prescribed technical requirements. In urban and agricultural areas, borrowed soil is not easily available and must therefore be transported over long distances. Quite often, large areas are covered by highly plastic and expansive soil, which is not suitable for the construction of substructure. Given the fact that approximately 7 million tons/year of fly ash and slag are produced in Serbian power plants, it was necessary to explore the possibility of fly ash and slag utilization for the construction of railway substructure in the Repub- lic of Serbia. The idea was based on the positive French experience at the high speed rail line LGV Est Européenne (often shortened to LGV Est, designed for speeds of $320 \mathrm{~km} / \mathrm{h}$ ) where approximately $150000 \mathrm{~m}^{3}$ of wet ashes from a landfill located at the thermal power plant were successfully used (Prel 2002).

The authors conducted this research at the Laboratory of Soil Mechanics at the Faculty of Civil Engineering of the University of Belgrade (Serbia) from May 2014 to May 2015.

\section{Environmental and Economic Aspects of Fly Ash Utilization in Railway Substructure}

The General Master Plan for Transport in Serbia (Italferr S.p.A. 2009) recognizes eight sections on Corridor X that need to be reconstructed. The costs of these projects are given in Table 1.

Fig. 2 shows the Serbian railway network with marked sections on Corridor X that are designated in Table 1, and the position of power plants with distances from each power plant to Belgrade. In the area of the Obrenovac, Kostolac and Svilajnac power plants, about 300 million tons of fly ash and slag are disposed in landfills, occupying an area of approximately 1600 hectares (American Coal Ash Association 2003; Baščarević et al. 2006). Fig. 2 shows a favourable position of RLC29 construction site to the power plants.

The reasons for the research conducted in the Republic of Serbia are:

- health protection of the population and prevention of ecosystem degradation in the region of the landfills in Obrenovac, Kostolac and Svilajnac (Fig. 3);

- ecological benefit by using industrial residues and preservation of non-renewable mineral resources, the removal of ash and slag landfills and land use for other purposes;

Table 1. Railway projects on Corridor X in Serbia (Italferr S.p.A. 2009)

\begin{tabular}{|c|c|c|c|c|c|}
\hline$\#$ & Project & Section & Cost $[\mathrm{mln} €]$ & Length $[\mathrm{km}]$ & Unit cost $[\mathrm{mln} € / \mathrm{km}]$ \\
\hline \multirow{2}{*}{1} & \multirow{2}{*}{ RLC13 } & \multirow{2}{*}{$\begin{array}{l}\text { Stara } \\
\text { Pazova-Subotica* }\end{array}$} & 286 & 185 & 1.55 \\
\hline & & & 555 & 150 & 3.70 \\
\hline 2 & RLB8 & Stara Pazova-Šid & 206 & 87 & 2.37 \\
\hline \multirow{2}{*}{3} & \multirow{2}{*}{ RLC29 } & \multirow{2}{*}{ Resnik-Velika Plana* } & 111 & 76 & 1.46 \\
\hline & & & 363 & 70 & 5.19 \\
\hline 4 & RLB927 & Velika Plana-Stalać & 212 & 88 & 2.41 \\
\hline 5 & RLC15 & Stalać-Đunis & 128 & 17 & 7.53 \\
\hline 6 & RLB928 & Đunis-Trupale ${ }^{* *}$ & 96 & 40 & 2.40 \\
\hline \multirow{2}{*}{7} & \multirow{2}{*}{ RLC16 } & \multirow{2}{*}{ Niš-Preševo* } & 285 & 156 & 1.83 \\
\hline & & & 629 & 156 & 4.03 \\
\hline \multirow{2}{*}{8} & \multirow{2}{*}{ RLC17 } & \multirow{2}{*}{ Niš-Dimitrovgrad ${ }^{*}$} & 226 & 104 & 2.17 \\
\hline & & & 440 & 104 & 4.23 \\
\hline
\end{tabular}

Notes:

* Single track railway:

- first row is the cost of upgrading to $160 \mathrm{~km} / \mathrm{h}$;

- second row is the cost of double track for $160 \mathrm{~km} / \mathrm{h}$;

** Single track railway: overall costs of upgrading to $160 \mathrm{~km} / \mathrm{h}$ and construction of second track. 


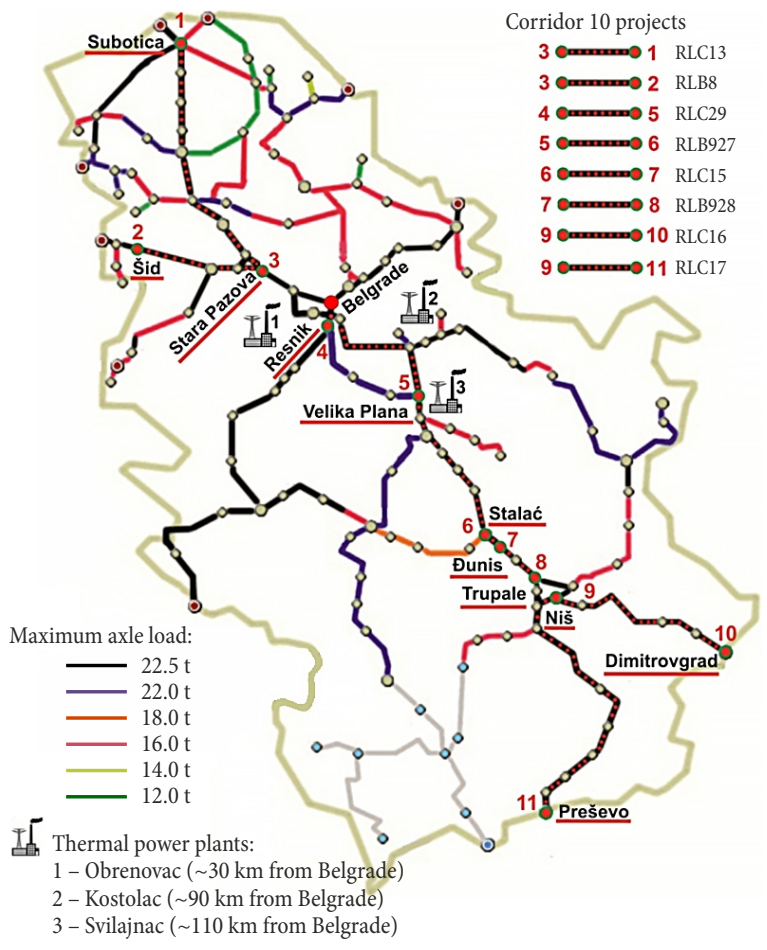

Fig. 2. The position of the power plants at the Corridor X in Serbia

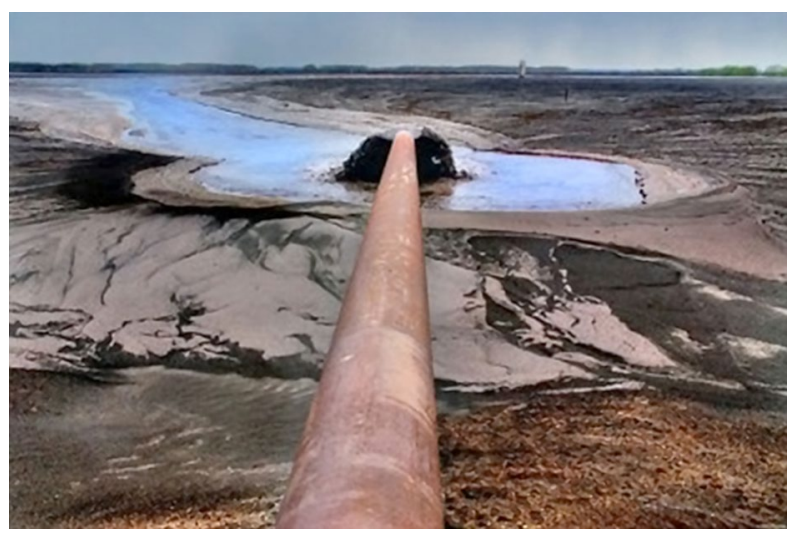

Fig. 3. The look of fly ash and slag landfill and devastated environment (the pipeline length is approximately $6.5 \mathrm{~km}$ from the thermal power plant Kostolac to the ash pond)

- the economic benefit due to the construction of embankments using cheap materials (the ash price at power plants is $0.00 €$ according to the Government decision and landfills are located near the construction sites), lower costs for compaction, utilization in embankment construction on weak subsoil (ash and slag have low specific gravities compared to soil).

\section{Technical Requirements for the Railway Substructure}

The requirements for the railway infrastructure on Corridor $\mathrm{X}$ were defined according to the Technical Specification for Interoperability (TSI) relating to the infra- structure' subsystem of the trans-European conventional rail system (EC 2011a). Table 2 shows TSI categories of lines for the conventional rail infrastructure subsystem. After reconstruction, infrastructure on Corridor X through the Republic of Serbia should meet the technical requirements of category $\mathrm{V}$ - Upgraded core TEN line (highlighted row in the Table 2).

Table 2. TSI categories of railway lines (EC 2011a)

\begin{tabular}{|l|c|c|c|}
\hline \multicolumn{1}{|c|}{ TSI categories } & $\begin{array}{c}\text { Passenger } \\
\text { traffic (P) }\end{array}$ & $\begin{array}{c}\text { Freight } \\
\text { traffic (F) }\end{array}$ & $\begin{array}{c}\text { Mixed } \\
\text { traffic (M) }\end{array}$ \\
\hline $\begin{array}{l}\text { New core } \\
\text { TEN line (IV) }\end{array}$ & IV-P & IV-F & IV-M \\
\hline $\begin{array}{l}\text { Upgraded core } \\
\text { TEN line (V) }\end{array}$ & V-P & V-F & V-M \\
\hline $\begin{array}{l}\text { New other } \\
\text { TEN line (VI) }\end{array}$ & VI & VI & VI \\
\hline $\begin{array}{l}\text { Upgraded other } \\
\text { TEN line (VII) }\end{array}$ & VII & VII & VII \\
\hline
\end{tabular}

The performance levels for each TSI category of line were defined by (EC 2011a). The upgraded core TEN lines (V) have the following performance: GB structure gauge, $22.5 \mathrm{t}$ axle load, $160 \mathrm{~km} / \mathrm{h}$ speed on passenger and mixed line, $100 \mathrm{~km} / \mathrm{h}$ speed on freight line, $600 \mathrm{~m}$ freight train length and $300 \mathrm{~m}$ passenger train length. The mentioned performances specify the minimum requirements for infrastructure on Corridor $\mathrm{X}$ through Serbia.

The typical technical parameters for the bearing capacity and the dimensioning of track formation and earth formation (track on earth formation, Fig. 4), were defined by each Infrastructure Manager. Technical requirements for substructure according to Serbian technical regulation (Železnice Srbije 2006) are given in Table 3.

In addition, the technical requirements for the main line on the Corridor X in Serbia (Serbian technical regulation - Železnice Srbije (2012)) include the following:

- embankment height $>2.0 \mathrm{~m}$, beneath prepared layer:

- depth up to $2.0 \mathrm{~m}: E_{V 2}=45 \mathrm{MN} / \mathrm{m}^{2}$ or $100 \%$ of the maximum dry density as determined from the Standard Proctor test;

- depth > $2.0 \mathrm{~m}: E_{V 2}=20 \mathrm{MN} / \mathrm{m}^{2}$ or $95 \%$ of the maximum dry density;

- embankment height $\leq 2.0 \mathrm{~m}$, beneath prepared layer: $E_{V 2}=45 \mathrm{MN} / \mathrm{m}^{2}$ or $100 \%$ of the maximum dry density as determined from the Standard Proctor test.

The values in Table 3 are consistent with the recommendations contained in UIC Code 719 R 'Earthworks and Track-Bed Layers for Railway Lines' (UIC 1994). Generally, recommended degree of compaction and minimum deformation moduli for each substructure layer are shown in Table 4. 


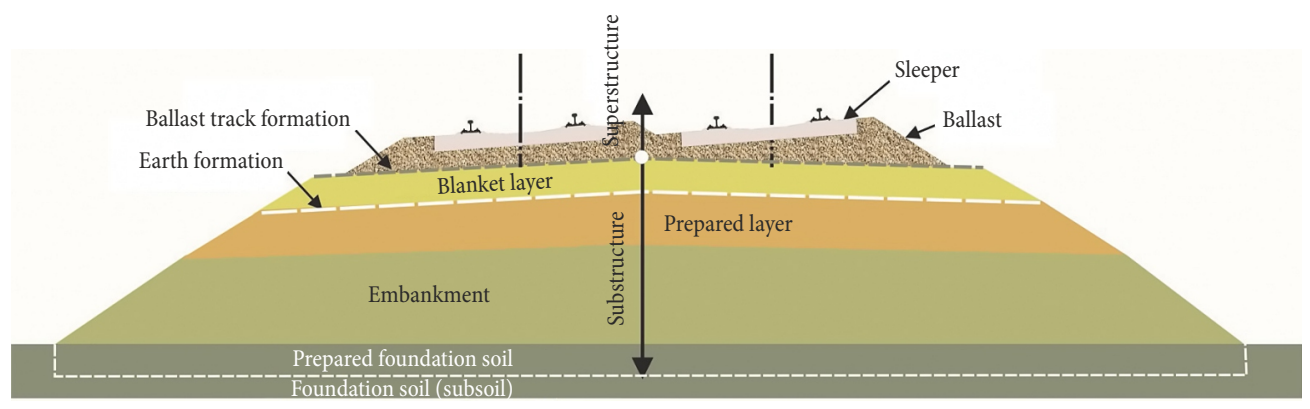

Fig. 4. Schematic railway cross section for track in curve

Table 3. Minimum values of the modulus of deformation, Proctor density and modulus of dynamic deformation for railway lines in Serbia (Železnice Srbije 2006)

\begin{tabular}{|c|c|c|c|c|c|c|c|c|c|}
\hline \multirow{2}{*}{\multicolumn{2}{|c|}{$\begin{array}{c}\text { Railway line } \\
\text { type }\end{array}$}} & \multicolumn{4}{|c|}{ Ballast track formation } & \multicolumn{4}{|c|}{ Earth formation } \\
\hline & & \multirow{3}{*}{$\begin{array}{c}\text { Proctor } \\
\text { density } \\
D_{p r} \\
\\
1.00 \\
(100 \%)\end{array}$} & \multirow{3}{*}{$\begin{array}{c}\begin{array}{c}\text { Modulus } \\
\text { of static } \\
\text { deformation } \\
E_{V 2}\left[\mathrm{MN} / \mathrm{m}^{2}\right]\end{array} \\
120\end{array}$} & \multirow{3}{*}{$\begin{array}{l}\text { Degree of } \\
\text { irregularity }\end{array}$} & \multirow{3}{*}{$\begin{array}{c}\begin{array}{c}E_{v d i n} \\
{\left[\mathrm{MN} / \mathrm{m}^{2}\right]}\end{array} \\
\\
50\end{array}$} & \multirow{3}{*}{$\begin{array}{c}D_{p r} \\
1.00 \\
(100 \%)\end{array}$} & \multirow{3}{*}{$\begin{array}{c}\begin{array}{c}\text { Modulus } \\
\text { of static } \\
\text { deformation } \\
E_{V 2}\left[\mathrm{MN} / \mathrm{m}^{2}\right]\end{array} \\
80\end{array}$} & Soil type & \multirow{2}{*}{$\begin{array}{c}\begin{array}{c}\text { Modulus } \\
\text { of dynamic } \\
\text { deformation }\end{array} \\
E_{\text {vdin }}\left[\mathrm{MN} / \mathrm{m}^{2}\right] \\
40\end{array}$} \\
\hline \multirow{6}{*}{ 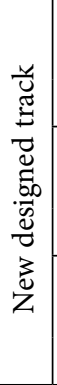 } & \multirow{2}{*}{$\begin{array}{l}\text { Main } \\
\text { railways }\end{array}$} & & & & & & & $\begin{array}{l}\text { GU, GP, GW, } \\
\text { GF, SP, SW }\end{array}$ & \\
\hline & & & & & & & & other type & 35 \\
\hline & \multirow{2}{*}{$\begin{array}{l}\text { Regional } \\
\text { railways }\end{array}$} & \multirow{2}{*}{$\begin{array}{c}1.00 \\
(100 \%)\end{array}$} & \multirow[t]{2}{*}{100} & \multirow{8}{*}{$>15$} & \multirow[t]{2}{*}{45} & \multirow{2}{*}{$\begin{array}{c}0.97 \\
(97 \%)\end{array}$} & \multirow[t]{2}{*}{60} & $\begin{array}{l}\text { GU, GP, GW, } \\
\text { GF, SP, SW }\end{array}$ & 35 \\
\hline & & & & & & & & other type & 30 \\
\hline & & \multirow{2}{*}{$\begin{array}{c}0.97 \\
(97 \%)\end{array}$} & \multirow[t]{2}{*}{80} & & \multirow[t]{2}{*}{40} & \multirow{2}{*}{$\begin{array}{c}0.95 \\
(95 \%)\end{array}$} & \multirow[t]{2}{*}{45} & $\begin{array}{l}\text { GU, GP, GW, } \\
\text { GF, SP, SW }\end{array}$ & 30 \\
\hline & & & & & & & & other type & 25 \\
\hline \multirow{4}{*}{ 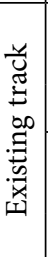 } & \multirow{2}{*}{$\begin{array}{l}V \geq 160 \\
\mathrm{~km} / \mathrm{h}\end{array}$} & \multirow{2}{*}{$\begin{array}{c}0.97 \\
(97 \%)\end{array}$} & \multirow[t]{2}{*}{80} & & \multirow[t]{2}{*}{40} & \multirow{2}{*}{$\begin{array}{c}0.95 \\
(95 \%)\end{array}$} & \multirow[t]{2}{*}{45} & $\begin{array}{l}\text { GU, GP, GW, } \\
\text { GF, SP, SW }\end{array}$ & 30 \\
\hline & & & & & & & & other type & 25 \\
\hline & \multirow{2}{*}{$\begin{array}{l}V<160 \\
\mathrm{~km} / \mathrm{h}\end{array}$} & \multirow{2}{*}{$\begin{array}{c}0.95 \\
(95 \%)\end{array}$} & \multirow[t]{2}{*}{50} & & \multirow[t]{2}{*}{35} & \multirow{2}{*}{$\begin{array}{c}0.93 \\
(93 \%)\end{array}$} & \multirow[t]{2}{*}{20} & $\begin{array}{l}\text { GU, GP, GW, } \\
\text { GF, SP, SW }\end{array}$ & 25 \\
\hline & & & & & & & & other type & 20 \\
\hline
\end{tabular}

Table 4. The degree of compaction and minimum deformation moduli in accordance with UIC Code $719 \mathrm{R}$

\begin{tabular}{|l|l|l|}
\hline Embankment fill: & $\geq$ & $\begin{array}{l}95 \% \text { of the maximum dry density as determined from the reference compaction test (Standard Proctor } \\
\text { test or Modified Proctor test depending on the type of line, high of the embankment and country) }\end{array}$ \\
\hline$\rho_{d}$ (dry density) & $\geq$ & $45 \mathrm{MN} / \mathrm{m}^{2}$ for fine soils or $60 \mathrm{MN} / \mathrm{m}^{2}$ for sandy and gravelly soils \\
\hline$E_{V 2}$ & $\leq$ & 2.2 for $E_{V 1}$ less than the minimum value prescribed $E_{V 2}$ \\
\hline$E_{V 2} / E_{V 1}$ & $\geq$ & $80 \mathrm{MN} / \mathrm{m}^{2}$ \\
\hline Prepared subgrade or form layer:
\end{tabular}




\section{Testing Materials}

Four types of waste materials from Serbian power plants were laboratory tested:

- ash-slag mixture from landfill at the 'Nikola Tesla A' thermal power plant (TENT A),

- fly ash from silos in the 'Nikola Tesla B' thermal power plant (TENT B),

- ash-slag mixture from landfills at the 'Kostolac A' and 'Kostolac B' thermal power plants and 'Srednje kostolačko ostrvo' landfill (TEKO AB), and

- fly ash from the 'Kostolac' thermal power plant (TEKO).

The chemical composition of the materials used is given in Table 5. More detailed chemical investigations of the fly ash from TENT A were carried out in the research by Popovic and Djordjevic (2015a, 2015b).

Due to the $\mathrm{SiO}_{2}+\mathrm{Al}_{2} \mathrm{O}_{3}+\mathrm{Fe}_{2} \mathrm{O}_{3}$ content being above $70 \%$, the sulphur trioxide $\mathrm{SO}_{3}$ content is $4 \%$ less and $\mathrm{CaO}$ content is $10 \%$ less, with the used ashes belonging to class F (according to ASTM C618-15) or siliceous type V (according to EN 197-1:2013).

According to the Serbian 'Regulation on the Limits of Radioactive Contamination of People and Environment and Methods for Decontamination' from 1999, the content of radionuclides of ash and slag from the Serbian thermal power plants is less than the defined limit for construction materials (Agencija za zaštitu... 1999). Based on the content of heavy metals, the ash and slag belong to inert waste marked as W177-GG040-32050 (according to EU regulations). The label was assigned by the Agency for Recycling of Serbia.

The effectiveness of stabilizing the fly ash and fly ash-slag mixture with next binders was investigated:

- hydrated lime, 'Jelen Do', dosage 5 and 7\%;

- Portland composite cement PC 35M (V-L) 32.5R, 'Titan', Kosjeric, dosage 2 and $4 \%$.

\section{Testing Methods}

Laboratory methods, according to Serbian standards (SRPS), were used to determine the physical and mechanical properties of the ashes and mixtures.

Grain size analysis was performed according to SRPS CEN ISO/TS 17892-4:2011.
Atterberg limits were determined using SRPS CEN ISO/TS 17892-12:2011 and specific gravity was determined according to SRPS CEN ISO/TS 17892-3:2012.

Permeability was determined using the falling head permeability test method, according to SRPS U.B1.034:1970 on the cylindrical samples with a diameter of $50 \mathrm{~mm}$ and height of $100 \mathrm{~mm}$.

Compaction tests were performed following SRPS U.B1.038:1997 standard. One-dimensional consolidation tests were conducted according to SRPS CEN ISO/TS 17892-5:2011 on samples with a diameter of $70 \mathrm{~mm}$ and a height of $20 \mathrm{~mm}$. The specimens were soaked for 24 hours before compression and then loaded incrementally to a maximum vertical stress of $400 \mathrm{kPa}$.

Direct shear tests were performed according to SRPS CEN ISO/TS 17892-10:2011 on the samples with a square base of $60 \times 60 \mathrm{~mm}$ and a height of $30 \mathrm{~mm}$. Prior to the shear, the saturated specimens were consolidated with vertical stresses of 100,200 and $400 \mathrm{kPa}$. The equipment used in these tests was with controlled strain rate.

California Bearing Ratio (CBR) tests were performed according to SRPS EN 13286-47:2012 on fully soaked samples.

\section{Test Results}

Physical properties, permeability and moisture-density relationship of the tested materials (TENT A, TENT B, TEKO AB, TEKO) without binders are shown in Table 6.

The testing samples for the investigation of the mechanical properties were prepared at optimum moisture content by Standard compaction Proctor test. Samples were tested two hours after compaction, as well as after 7 and 28 days.

\subsection{Shear Strength Parameters in Terms of Effective Stresses}

Shear strength parameters in terms of effective stresses were determined using direct shear test. Obtained results (Fig. 5) have shown that the friction angle after 28 days was in the range of $\varphi^{\prime}=30-35^{\circ}$ without the addition of binders. With the addition of cement or lime, the friction angle increases to $\varphi^{\prime}=38-45^{\circ}$. Friction angles of tested ash-slag mixture and fly ash are in the range of sand and gravel. Cohesion additionally increases the total shear strength.

Table 5. Chemical composition of used fly ash/ash-slag mixture, mean value in the period 1984-2004 (Institut IMS 2015; Institut za puteve 2008)

\begin{tabular}{|l|c|c|c|c|c|c|c|c|}
\hline Fly ash/ash-slag mix & $\mathrm{SiO}_{2}$ & $\mathrm{Al}_{2} \mathrm{O}_{3}$ & $\mathrm{Fe}_{2} \mathrm{O}_{3}$ & Reactive $\mathrm{CaO}$ & $\mathrm{MgO}$ & $\mathrm{K}_{2} \mathrm{O}$ & $\mathrm{Na}_{2} \mathrm{O}$ & $\mathrm{SO}_{3}$ \\
\hline TENT A & 51.6 & 23.83 & 5.54 & 1.06 & 3.01 & 1.05 & 0.57 & 0.85 \\
\hline TENT B & 59.06 & 21.7 & 5.93 & 5.17 & 2.02 & 0.89 & 0.44 & 1.75 \\
\hline TEKO AB & 56.38 & 17.57 & 10.39 & 7.46 & 2.13 & 0.57 & 0.38 & 0.95 \\
\hline TEKO & 53.8 & 19.93 & 7.56 & 6.26 & 1.28 & 0.8 & 0.58 & 2.76 \\
\hline
\end{tabular}

Note: values may not be entirely representative of tested material, as over time the chemical content of the coal used by the power plants may have changed. 
Table 6. Physical properties, permeability and moisture-density relationship of the tested materials without binders

\begin{tabular}{|c|c|c|c|c|c|c|c|}
\hline \multicolumn{4}{|c|}{ Type of material (etalons) } & TENT A & TENT B & TENT AB & TEKO \\
\hline \multirow{7}{*}{$\begin{array}{l}\text { The basic } \\
\text { physical } \\
\text { properties }\end{array}$} & \multicolumn{3}{|c|}{ Specific gravity $G_{s}$} & 2.39 & $2.24-2.27$ & 2.41 & 2.22 \\
\hline & & \multicolumn{2}{|c|}{ (clay) $<0.002 \mathrm{~mm}$} & $0-1$ & 2 & 2 & 0 \\
\hline & & \multicolumn{2}{|c|}{ (silt) $0.002-0.06 \mathrm{~mm}$} & $10-22$ & $40-41$ & $14-31$ & 75 \\
\hline & Grain size & \multicolumn{2}{|c|}{ (sand) $0.06-2.0 \mathrm{~mm}$} & $77-89$ & $57-58$ & $65-82$ & 25 \\
\hline & & \multicolumn{2}{|c|}{ (gravel) $2.0-60.0 \mathrm{~mm}$} & 0 & 0 & 2 & 0 \\
\hline & & \multicolumn{2}{|c|}{ (fractions) $<0.075 \mathrm{~mm}$} & $14-27$ & $49-50$ & $22-40$ & 80 \\
\hline & \multicolumn{3}{|c|}{ Consistency limits } & \multicolumn{4}{|c|}{ non-plastic material } \\
\hline & \multicolumn{3}{|c|}{ Permeability $K_{f}[\mathrm{~m} / \mathrm{s}]$} & $8.0 \cdot 10^{-7}$ & $7.2 \cdot 10^{-7}$ & & $5.4 \cdot 10^{-6}$ \\
\hline & \multirow{2}{*}{\multicolumn{2}{|c|}{$\begin{array}{l}\text { Moisture-density } \\
\text { relationship Proctor } \\
\text { test } 600 \mathrm{kNm} / \mathrm{m}^{3}\end{array}$}} & $\gamma_{d, \max }\left[\mathrm{kN} / \mathrm{m}^{3}\right]$ & 8.91 & 10.37 & 9.12 & 10.37 \\
\hline & & & $\mathrm{w}_{\text {opt }}[\%]$ & 48.5 & 33.7 & 48.1 & 33.7 \\
\hline
\end{tabular}
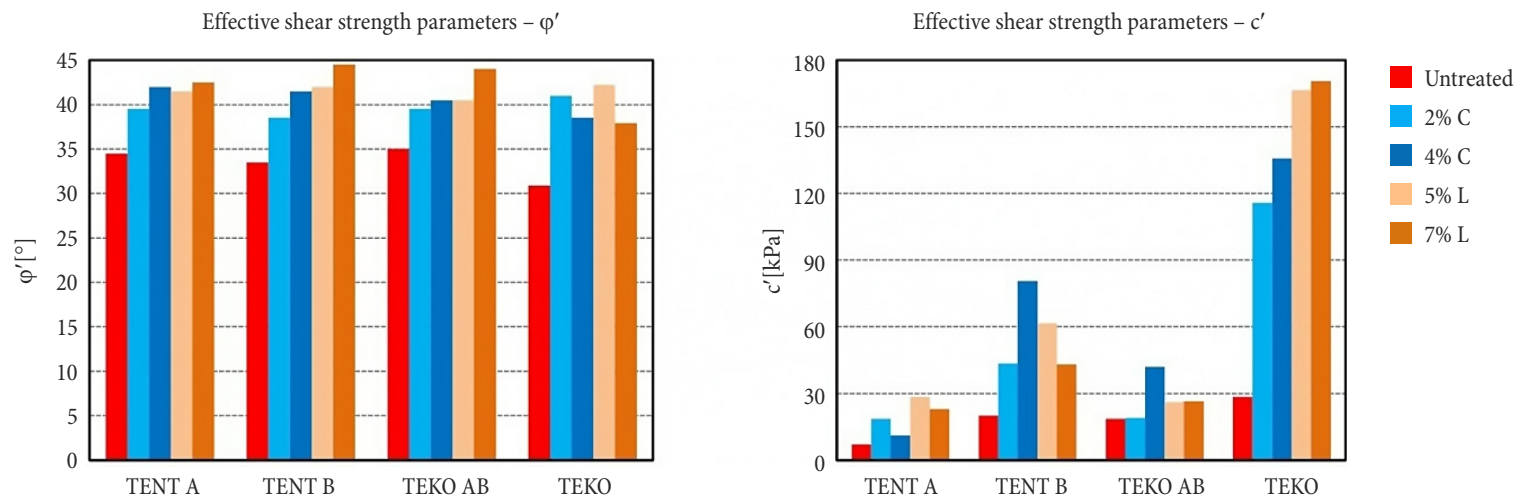

Fig. 5. Effective shear strength parameters after 28 days: $\varphi^{\prime}-$ friction angle; $c^{\prime}-$ cohesion

\subsection{California Bearing Ratio}

The CBR values of basic testing materials and with the addition of binders are shown in Fig. 6. CBR values of basic testing materials are different: $7 \%$ for TENT A, 12\% for TENT B, 24\% for TEKO AB, 55\% for TEKO. With the addition of binders, the obtained results showed significant gain. In the case of TENT A and TENT B, CBR value increased in the range of $90-150 \%$, for TEKO $A B$ in the range of $75-190 \%$ and for TEKO in the range of 140-230\%.

The estimated values of modulus of static deformation $E_{V 2}$ calculated from the correlation with CBR (Gomes Correia 2004) are shown in Fig. 7. The values of $E_{V 2}$, of basic testing materials are: $30 \mathrm{MPa}$ for TENT A, $44 \mathrm{MPa}$ for TENT B, $72 \mathrm{MPa}$ for TEKO AB and 132 $\mathrm{MPa}$ for TEKO. With the addition of binders, $E_{V 2}$ values increased: for TENT A in the range of 170-260 MPa, for TENT $\mathrm{B}$ and TEKO AB in the range of 170-370 $\mathrm{MPa}$ and for TEKO in the range of 270-440 MPa.

\subsection{Deformation Parameters}

The compressibility modulus for basic testing materials is in range $M_{V(50-100)}=10-24 \mathrm{MPa}$ and $M_{V(100-}$ 200) $=20-39 \mathrm{MPa}$ and increases significantly with the addition of binders up to 50-70 $\mathrm{MPa}$ (Fig. 8).

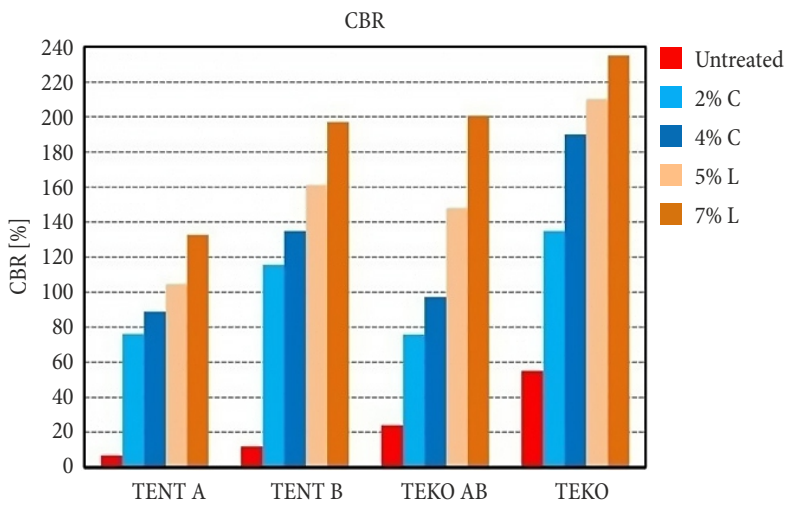

Fig. 6. CBR values of tested materials after 28 days

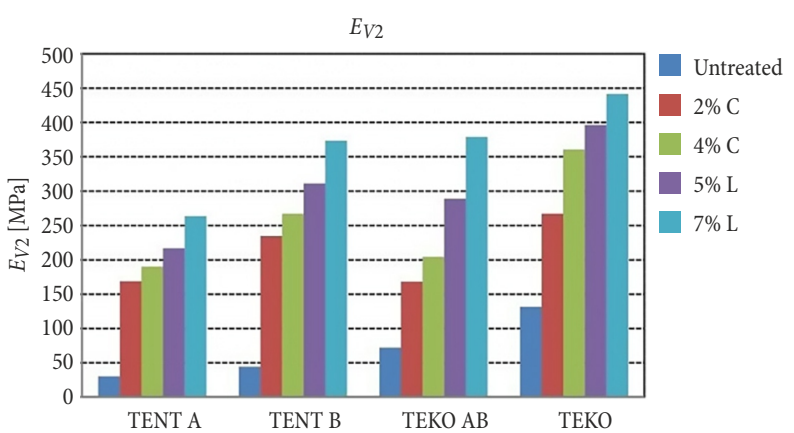

Fig. 7. Modulus of static deformation of tested materials correlation with CBR according to Gomes Correia (2004) 


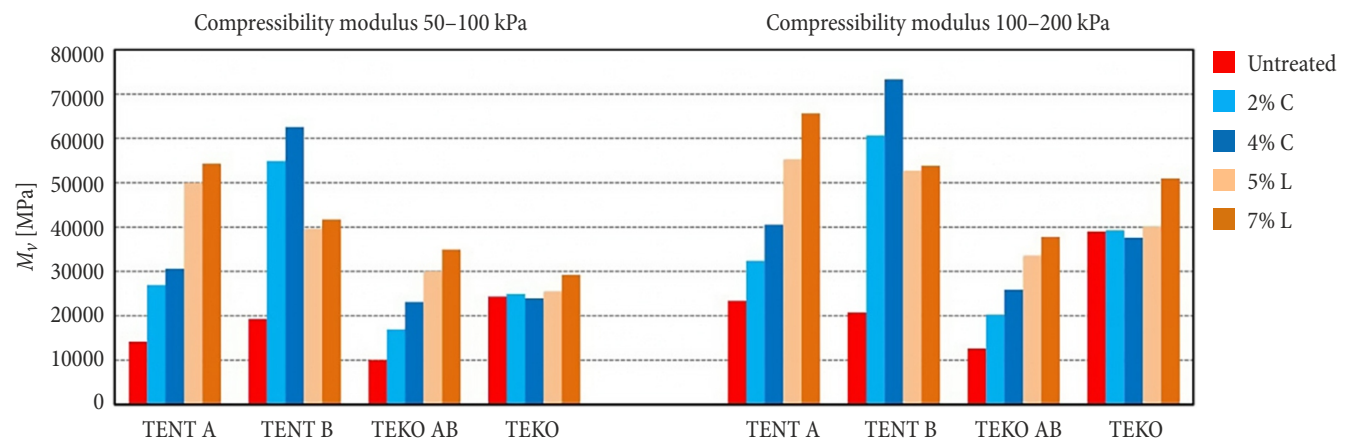

Fig. 8. Compressibility modulus of tested materials after 28 days

\section{Discussion}

An ideal fill material for the railway embankment should have the following properties:

- high bearing capacity referring to static and dynamic loads;

- minor settlement and good consolidation;

- high structural resistance;

- vertical elasticity;

- stability to erosion;

- good water permeability;

- volume and filter stability referring to the ballast (above) and subsoil (below);

- frost resistance;

- cost effectiveness (supply, transport, construction and maintenance);

- to be environmentally friendly.

In addition, embankment fill material must meet the technical requirements for railway infrastructure. At the same time, mutual adjustment of stiffness of superstructure and substructure elements is necessary to be achieved along the track (Puzavac et al. 2012).

Studies on the use of self-cementing fly ash for soil stabilization have been conducted by a number of researchers so far. Many scientific results have shown that the self-cementing fly ash is an effective and economical stabilizing agent for a wide variety of construction applications. However, fly ash from the Serbian power plants has pozzolanic properties and because of low concentrations of calcium compounds (less than $10 \%$ $\mathrm{CaO})$, they are devoid of self-cementing characteristics. Because of this, it is usually necessary to add binders such as cement or lime to this type of ash in order to improve its mechanical properties, which can be observed in Figs 5-8.

Mechanical properties (CBR, shear strength parameters, compressibility modulus) of some of the investigated samples match technical requirements even without the addition of binders. With the addition of binders, all investigated ash samples match technical requirements.

According to values of $E_{V 2}$, which were obtained from the correlation with CBR (Fig. 7), we can conclude the following:

- ash-slag mixture from landfill, TENT A, without addition can be used for embankment layers at a depth $>2.0 \mathrm{~m}$ beneath the prepared formation layer; with addition of $2 \%$ of cement or $5 \%$ of lime, this material met the bearing capacity requirements for prepared formation layer and for embankment layers at a depth $<2.0 \mathrm{~m}$ beneath the prepared formation layer;

- fly ash TENT B, without addition satisfied the bearing capacity requirements for embankment layers at depth $<2.0 \mathrm{~m}$ beneath the prepared formation layer; with addition of $2 \%$ of cement or $5 \%$ of lime, this material met the bearing capacity requirements for prepared formation layer.

- fly ash TEKO and ash-slag mixture TEKO AB met the bearing capacity requirements for prepared formation layer even without additions.

Frost resistance index of some of investigated ash with binders is slightly lower than $80 \%$ (according to standard SRPS U.B1.050:1970), so it can be considered acceptable due to the high absolute values of unconfined compression (Institut IMS 2015).

\section{Conclusions}

The results of laboratory testing, as well as previous research in Serbia (Vukićević et al. 2013, 2015; Cmiljanić et al. 2010; Institut za puteve 2008) and many published papers (Ramadas 2012; Havanagi et al. 2011; Kolay et al. 2011; Senol et al. 2006; Parsons, Kneebone 2005; Nalbantoglu, Gucbilmez 2002; Pandian et al. 2002; Parsons 2002; Zia, Fox 2000) showed that investigated ashes (with or without or binder) are suitable for application in the railway substructure for:

- stabilization of soft subsoil (Fig. 9, left);

- construction of embankments using soil stabilized with ash;

- construction of embankments with the core of ash (Fig. 9, left);

- construction of embankments using ash;

- construction of prepared formation layer using ash with binders (cement or lime), for new designed track or in rehabilitation/reconstruction (Fig. 9, right);

- construction of prepared formation layer using ash stabilization of soil, for new designed tracks, or in rehabilitation/reconstruction;

- stabilization with the addition of ash in the construction of the hydraulically bonded bearing layer under concrete or asphalt bearing layer (Fig. 10); 
- construction of a bridge-embankment transition area (a cement stabilization is defined in railway standards, and utilization of ash should also be investigated for this stabilization, Fig. 11);

- construction of pavement for access roads to railway stations as well as manipulation areas (loading, reloading, or unloading zone, as well as parking lots and internal roads) at railway freight stations.

Despite the positive effects that have been shown based on the results of the laboratory testing, field verification of the results needs to be carried out. Further research is directed towards verification of the laboratory results by experimental construction of embankments with various types of ash and slag (with or without binders), which includes a control field investigations and laboratory testing.

\section{Funding}

Authors are grateful to the financial support of Electric Power Industry of Serbia via study 'Utilization of Fly Ash and Slag Produced in the TPP JP EPS Thermal Power Plants for Construction of Railways' and acknowledge the support of research project TR 36012, funded by the Ministry of Education and Science of the Republic of Serbia.

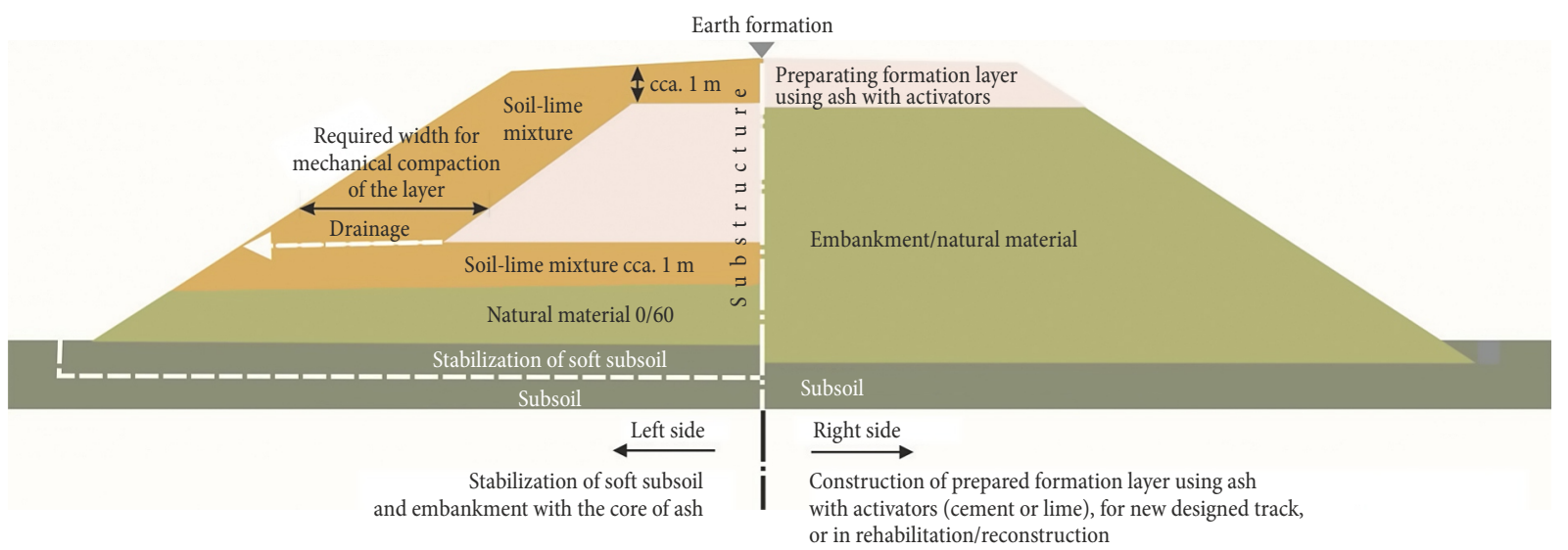

Fig. 9. The stabilization of soft subsoil and construction of embankments using soil stabilized with ash and construction of embankments with the core of ash (left side), and construction of prepared formation layer using ash with binders (right side)
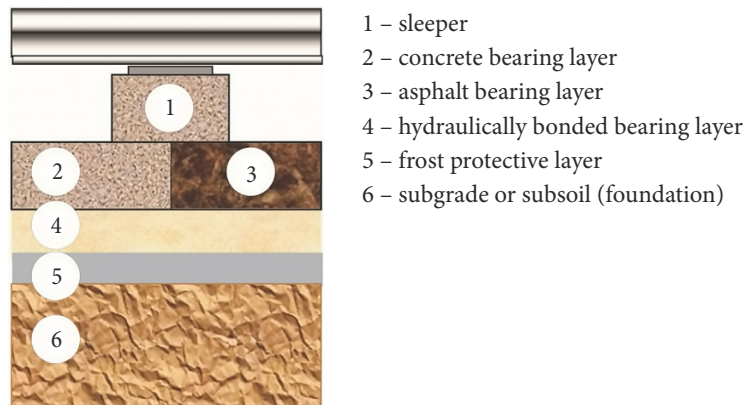

Fig. 10. Position of the hydraulically bonded bearing layer in the slab track structure

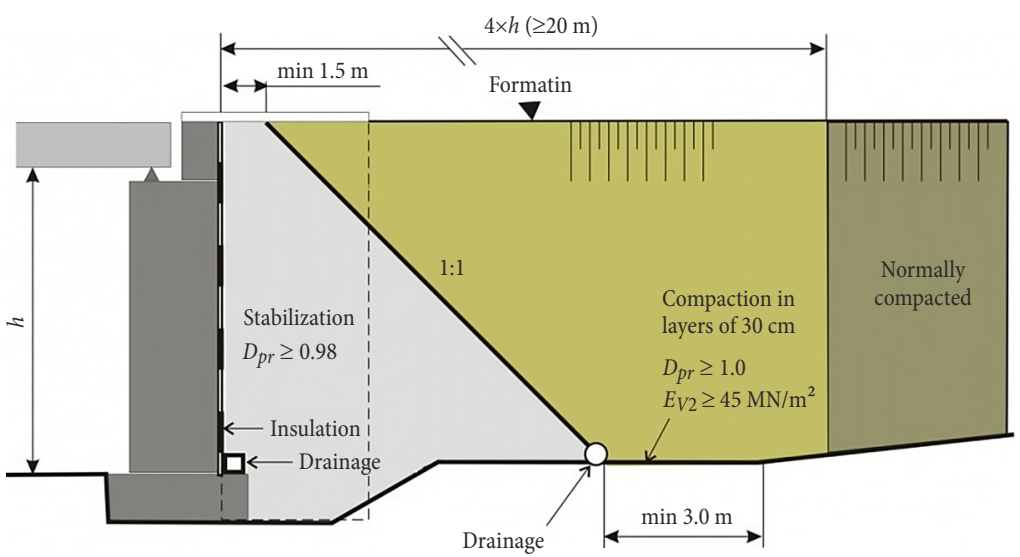

Fig. 11. The stabilization zone in the bridge-embankment transition area 


\section{References}

Agencija za zaštitu od jonizujućih zračenja i nuklearnu sigurnost Srbije. 1999. Pravilnik o granicama radioaktivne kontaminacije lica, radne $i$ životne sredine $i$ načinu sprovodenja dekontaminacije [Regulation on the limits of radioactive contamination of people and environment and methods for decontamination]. Available from Internet: http://www.srbatom.gov.rs/srbatom/doc/vazeca_akta/5\%20 Pravilnik\%20o\%20\%20granicama\%20kontaminacije\%20 lica\%20radne\%20i\%20zivotne\%20sredine\%20lat.pdf (in Serbian).

American Coal Ash Association. 2003. Fly ash facts for highway engineers. Technical Report No FHWA-IF-03-019, US. 81 p. Available from Internet: http://www.fhwa.dot.gov/ pavement/recycling/fach00.cfm

ASTM C618-15. Standard Specification for Coal Fly Ash and Raw or Calcined Natural Pozzolan for Use in Concrete.

Baščarević, Z.; Komljenović, M.; Petrašinović-Stojkanović, L.; Jovanović, N.; Rosić, A.; Ršumović, M. 2006. Ispitivanje svojstava elektro-filterskog pepela termoelektrana u cilju njegove upotrebe kao sekundarne sirovine za proizvodnju portland-cementnog klinkera, Hemijska industrija 60(910): 245-252. (in Serbian).

http://doi.org/10.2298/HEMIND0610245B

Cmiljanić, S.; Vujanić, V.; Rosić, B.; Vuksanović, B.; Tošović, S.; Jotić, S. 2010. Physical-mechanical properties of fly-ash originating from thermo-electric power plants of Serbia, in Proceedings of the 14th Danube-European Conference on Geotechnical Engineering: From Research to Design in European Practice, 2-4 June 2010, Bratislava, Slovakia, 1-9 (CD).

EC. 2011a. Commission Decision of 26 April 2011 Concerning a Technical Specification for Interoperability Relating to the 'Infrastructure' Subsystem of the Trans-European Conventional Rail System. Notified under document C(2011) 2741. 2011/275/EU. 68 p. Available from Internet: http://eur-lex. europa.eu/legal-content/EN/TXT/PDF/?uri=CELEX:32011 D0275\&from $=\mathrm{EN}$

EC. 2011b. White Paper: Roadmap to a Single European Transport Area - Towards a Competitive and Resource Efficient Transport System. COM(2011) 144 final. 28.3.2011, Brussels. Available from Internet: http://eur-lex.europa.eu/legalcontent/EN/ALL/?uri=CELEX:52011DC0144

EN 197-1:2011. Cement - Part 1: Composition, Specifications and Conformity Criteria for Common Cements.

Gomes Correia, A. 2004. Conception des chaussées: approche mécanique, caractérisation des matériaux et leuré valuation dans les plates-formes routière, in Les plate-formes d'infrastructures de transport - Conception, terrassement et contrôles, 20 octobre 2004, France, 67 p. Available from Internet: http://c.f.m.s.free.fr/Manifestations/041020/correia.pdf

Havanagi, V. G.; Sinha, A. K.; Mathur, S. 2011. Design and stability analysis of pond ash railway embankment, in Geotechnical Engineering for Disaster Mitigation and Rehabilitation and Highway Engineering 2011: Geotechnical and Highway Engineering - Practical Applications, Challenges and Opportunities, 18-20 May 2011, Semarang, Indonesia, 349-355. http://doi.org/10.1142/9789814365161_0041

Institut IMS. 2015. Korišcenje letećeg pepela i šljake proizvedenih u TE JP EPS zapotre beželeznice [Utilization of Fly Ash and Slag Produced in the TPP JP EPS Thermal Power Plants for Construction of Railways]. Beograd, Srbija. 163 s. (in Serbian).
Institut za puteve. 2008. Korišćenje letećeg pepela i šljake proizvedenih u termoelektrani "Nikola Tesla" (A i B) i termoelektrani "Kostolac" ( $A$ i B) za potrebe putogradnje [Utilization of fly ash and slag produced in the TPP "Nikola Tesla" (A and B) and TPP "Kostolac" (A and B) for construction of road]. Beograd, Srbija. 157 s. (in Serbian).

Italferr S.p.A. 2009. General Master Plan for Transport in Serbia. Final Report 05SER01/04/016. A project implemented by Italferr S.p.A. in association with IIPP, NEA and Witteveen+Bos. 189 p. Available from Internet: http://www. seetoint.org/wp-content/uploads/downloads/2014/01/Serbia_General-Master-Plan-for-Transport-2009.pdf

Kolay, P. K.; Sii, H. Y.; Taib, S. N. L. 2011. Tropical Peat Soil Stabilization using class $\mathrm{F}$ pond ash from coal fired power plant, International Journal of Civil, Environmental, Structural, Construction and Architectural Engineering 5(2): 71-75.

Ministarstvo građevinarstva, saobraćaja i infrastrukture Republike Srbije. 2014. Projekti u realizaciji. Beograd, Srbija, 232 s. Available from Internet: http://www.mgsi.gov.rs/ sites/default/files/Projekti,\%20srpski\%20Z,\%202014..pdf (in Serbian).

Nalbantoglu, Z.; Gucbilmez, E. 2002. Utilization of an industrial waste in calcareous expansive clay stabilization, Geotechnical Testing Journal 25(1): 78-84. http://doi.org/10.1520/GTJ11082J

Pandian, N. S.; Krishna, K. C.; Leelavathamma, B. 2002. Effect of fly ash on the CBR behaviour of soils, in Geotechnical Engineering, Environmental Challenges: Indian Geotechnical Conference, 20-22 December 2002, Allahabad, India, 1: 183-186.

Parsons, R. L. 2002. Subgrade Improvement Through Fly Ash Stabilization. Report, Kansas University Transportation Center, US. $16 \mathrm{p}$.

Parsons, R. L.; Kneebone, E. 2005. Field performance of fly ash stabilised subgrades, Proceedings of the Institution of Civil Engineers - Ground Improvement 9(1): 33-38. http://doi.org/10.1680/grim.2005.9.1.33

Popovic, A.; Djordjevic, D. 2015a. Trace and major elements in ash of "Nikola Tesla A" power plant dump (I) - leached concentrations and environmental implications, Energy Sources, Part A: Recovery, Utilization, and Environmental Effects 37(11): 1224-1232. http://doi.org/10.1080/15567036.2011.606872

Popovic, A.; Djordjevic, D. 2015b. Trace and major elements in ash of "Nikola Tesla A" power plant dump (II) - associations of elements in active cassette ash, Energy Sources, Part A: Recovery, Utilization, and Environmental Effects 37(12): 1291-1299. http://doi.org/10.1080/15567036.2011.615804

Popović, Z.; Lazarević, L. 2013. The role of railway in the European transport policy, Izgradnja 67(7): 285-291.

Popović, Z.; Lazarević, L.; Ižvolt, L. 2013. Potential of the Railway infrastructure in Serbia, Railway Transport and Logistics: Scientific-Technical Journal for Railway Transport and Carriage, Logistics and Management 9(3): 9-22.

Popović, Z.; Trpčevski, F.; Pančić, I.; Lazarević, L. 2014. Harmonizacija evropskog kvaliteta koloseka - Harmonization of European track quality, Građevinski materijali i konstrukcije - Building Materials and Structures 57(1): 29-44. http://doi.org/10.5937/grmk1401029P

Prel, G. 2002. Embankment for Railway Construction of the LGV Line (2002-2003). Presentation, Paris, France. 24 p. 
Puzavac, L.; Popović, Z.; Lazarević, L. 2012. Influence of track stiffness on track behaviour under vertical load, Promet Traffic\&Transportation 24(5): 405-412. http://doi.org/10.7307/ptt.v24i5.1176

Ramadas, T. L.; Kumar, N. D.; Yesuratnam, G. 2012. A study on strength and swelling characteristics of three expansive soils treated with fly ash, in International Symposium on Ground Improvement (IS-GI BRUSSELS 2012): Recent Research, Advances \& Execution Aspects of Ground Improvement Works, 31 May - 1 June 2012, Brussels, Belgium, 2: 459-466.

Senol, A.; Edil, T. B.; Bin-Shafique, M. S.; Acosta, H. A.; Benson, C. H. 2006. Soft subgrades' stabilization by using various fly ashes, Resources, Conservation and Recycling 46(4): 365-376. http://doi.org/10.1016/j.resconrec.2005.08.005

SRPS CEN ISO/TS 17892-3:2012. Geotehničko istraživanje $i$ ispitivanje - Laboratorijsko ispitivanje tla - Deo 3: Određivanje mase jedinične zapremine čestica piknometarskom metodom [Geotechnical Investigation and Testing Laboratory Testing of Soil - Part 3: Determination of Particle Density - Pycnometer Method] (in Serbian).

SRPS CEN ISO/TS 17892-4:2011. Geotehničko istraživanje $i$ ispitivanje - Laboratorijsko ispitivanje tla - Deo 4: Odredivanje granulometrijskog sastava [Geotechnical Investigation and Testing - Laboratory Testing of Soil - Part 4: Determination of Particle Size Distribution] (in Serbian).

SRPS CEN ISO/TS 17892-5:2011. Geotehničko istraživanje $i$ ispitivanje - Laboratorijsko ispitivanje tla - Deo 5: Edometarsko ispitivanje stepenastim opterećenjem [Geotechnical Investigation and Testing - Laboratory Testing of Soil Part 5: Incremental Loading Oedometer Test] (in Serbian).

SRPS CEN ISO/TS 17892-10:2011. Geotehničko istraživanje i ispitivanje - Laboratorijsko ispitivanje tla - Deo 10: Ispitivanje direktnog smicanja [Geotechnical Investigation and Testing - Laboratory Testing of Soil - Part 10: Direct Shear Tests] (in Serbian).

SRPS CEN ISO/TS 17892-12:2011. Geotehničko istraživanje $i$ ispitivanje - Laboratorijsko ispitivanje tla - Deo 12: Određivanje Aterbergovih granica [Geotechnical Investigation and Testing - Laboratory Testing of Soil - Part 12: Determination of Atterberg Limits] (in Serbian).

SRPS EN 13286-47:2012. Nevezane i hidrauličkim vezivom vezane mešavine - Deo 47: Metode ispitivanja za odredivanje kalifornijskog indeksa nosivosti, neposrednog indeksa nosivosti $i$ linearnog bubrenja [Unbound and Hydraulically Bound Mixtures - Part 47: Test Method for the Determination of California Bearing Ratio, Immediate Bearing Index and Linear Swelling] (in Serbian).

SRPS U.B1.034:1970. Geomehanička ispitivanja - Određivanje koeficijenata vodopropustljivosti [Testing of Soils - Determination of Coefficient of Permeability] (in Serbian).

SRPS U.B1.038:1997. Geomehanička ispitivanja - Odredivanje odnosa vlažnosti i suve zapreminske mase tla [Testing of Soil - Determination of the Relation Moisture Content Density of Soil] (in Serbian).

SRPS U.B1.050:1970. Geomehanička ispitivanja - Ispitivanje otpornosti cementom stabilizovanog tla prema mrazu [Testing of Soils - Resistance Cement Stabilized Soils to Freezing] (in Serbian).

UIC. 1994. Earthworks and Track-Bed Layers for Railway Lines. UIC Code 719 R. International Union of Railways (UIC). UIC Leaflet, Paris, France, 117 p.
Vukićević, M.; Pujević, V.; Marjanović, M.; Jocković, S.; MarašDragojević, S. 2015. Stabilization of fine-grained soils using non self-cementing fly ash, Građevinar 67(8): 761-770. http://doi.org/10.14256/JCE.1281.2014

Vukićević, M.; Pujević, V.; Marjanović, M.; Jocković, S.; MarašDragojević, S. 2013. Research results of fine-grained soil stabilization using fly ash from Serbian electric power plants, in 18th International Conference on Soil Mechanics and Geotechnical Engineering, 2-6 September 2013, Paris, France, 4: 3267-3270. Available from Internet: http://www. issmge.org/uploads/publications/1/2/3267-3270.pdf

Zia, N.; Fox, P. 2000. Engineering properties of loess-fly ash mixtures for roadbase construction, Transportation Research Record: Journal of the Transportation Research Board 1714: 49-56. http://dx.doi.org/10.3141/1714-07

Železnice Srbije. 2012. Pravilnik o projektovanju rekonstrukcije $i$ izgradnje određenih elemenata železničke infrastrukture pojedinih magistralnih železničkih pruga [Technical regulation for reconstruction of infrastructure elements on main rail lines]. Available from Internet: http://demo.paragraf. rs/demo/combined/Old/t/t2012_10/t10_0286.htm (in Serbian).

Železnice Srbije. 2006. Uputstvo 338 za kontrolu zbijenosti planuma železničke pruge korišćenjem [Technical guide No. 338 for compaction control of track formation using the light drop weight device]. 14 s. (in Serbian). 